\title{
SIFAT-SIFAT MEKANIK MATERIAL KOMPOSIT BERBAHAN DASAR FLY ASH DAN PASIR HALUS
}

\author{
La Ode Muhaimin ${ }^{1}$, Minson Simatupang ${ }^{2}$ \\ ${ }^{12}$ Jurusan Teknik Sipil, Universitas Halu Oleo, Indonesia \\ ${ }^{2}$ minson.simatupang@uho.ac.id
}

\begin{abstract}
ABSTRAK
Stabilisasi tanah dengan menggunakan fly ash menjadi salah satu alternatif menarik untuk dikembangkan. Disamping mengurangi limbah hasil buangan industri, juga ekonomis dari segi biaya. Dengan kehadiran air, kapur yang terdapat dalam fly ash akan terurai serta mengalami proses sementasi dan reaksi pozolan yang akan mengikat butiran pasir. Dalam penelitian ini pengaruh kandungan fly ash dan masa kuring terhadap besaran kuat tekan dan kuat geser diobservasi menggunakan alat uji tekan bebas dan uji geser langsung, secara berurutan. Hubungan tegangan-regangan akibat beban geser antara pasir tanpa fly ash dan pasir dengan fly ash dibandingkan untuk melihat peningkatan kuat geser akibat penambahan fly ash. Hasilnya menunjukkan bahwa kuat tekan bebas dan kuat geser material komposit meningkat seiring dengan penambahan fly ash dan masa kuring. Tetapi hal sebaliknya terjadi pada regangan tekan. Dikonfirmasi bahwa regangan untuk mencapai kuat tekan maksimum semakin berkurang dengan bertambahnya kadar fly ash dan masa kuring. Ikatan fly ash semakin getas dengan semakin meningkatnya kuat tekan material komposit berbahan dasar fly ash dan pasir halus.
\end{abstract}

Kata kunci: fly ash, masa kuring, pasir halus, kuat tekan bebas, kuat geser.

\begin{abstract}
Mechanical Properties of Composite Material formed from Fly Ash and Fine Sand. Soil stabilization using fly ash is an attractive alternative to be developed. Besides reducing industrial waste, it is also economical in terms of costs. With the presence of water, the lime contained in fly ash would be decomposed and undergone a cementation process and a pozolan reaction which would bind the sand grains. In this study, the effect of fly ash content and curing period on the amount of compressive strength and shear strength was observed using an unconfined compressive and direct shear test, respectively. The stress-strain relationships due to shear loads between sand without fly ash and sand with fly ash were compared to see an increase in shear strength due to the addition of fly ash. The results show that the unconfined compressive strength and shear strength of the composite material increase with the addition of fly ash and curing period. But the opposite happened in compressive strain. It was confirmed that the strain to achieve maximum compressive strength decreased with increasing fly ash content and curing period. The fly ash bond was getting brittle with the increasing compressive strength of the composite material made from fly ash and fine sand.
\end{abstract}

Keywords: fly ash, curing time, fine sand, unconfined compressive strength, shear strength.

\section{PENDAHULUAN}

Material komposit adalah material yang terbentuk dari dua atau lebih bahan yang berbeda, seperti fly ash dengan pasir, semen dengan tanah endapan, kapur dengan lempung, dan lain-lain. Pasir merupakan jenis tanah non kohesif, dimana ikatan antar butiran saling lepas (kekuatan geser rendah), dan memiliki gradasi butiran yang seragam. Konstruksi bangunan sipil yang akan dibangun di atas tanah dasar berpasir dengan gradasi butiran seragam sangatlah sulit dan membutuhkan biaya yang besar. Jika kondisi tanahnya dalam keadaan jenuh air itu sangat tidak baik bahkan berbahaya bila sewaktu - waktu terjadi gempa bumi pada skala tertentu karena berpotensi menimbulkan likuifaksi yang dampaknya sangat merugikan [1]-[3].

Tanah yang termasuk dalam kategori lempung $(0,06$ - 0,002 mm) dan pasir $(0,2-0,06 \mathrm{~mm})$ dengan kepadatan medium sangat berpotensi mengalami likuifaksi. Oleh karena itu diperlukan solusi untuk 
mengatasi serta memperbaiki (stabilisasi) kondisi tanah jenis ini. Salah satu upayanya adalah mencampurkan atau menambahkan bahan lain yang berupa serat (fiber) ataupun lembaran-lembaran sehingga mampu mengikat dan meningkatan kekuatan pada tanah pasir [4].

Tanah yang distabilisasi, secara umum, merupakan material komposit yang dihasilkan dari kombinasi dari bahan penyusunnya. Teknik stabilisasi sering digunakan untuk memperbaiki sifat-sifat geoteknik tanah aslinya. Teknik ini sering dilakukan melalui penambahan material yang mampu mengikat butiran tanah melalui proses presipitasi, seperti presipitasi kalsit [1]-[3], atau proses sementasi seperti semen, kapur, dan lain-lain. Proses sementasi menggunakan produk sampingan/limbah industri, seperti fly ash, menjadi suatu hal yang menarik untuk dipertimbangkan [5]-[10]. Disamping ekonomis dari segi biaya, juga bisa mengurangi pencemaran lingkungan.

Dewasa ini, fly ash telah dimanfaatkan dalam berbagai bidang konstruksi bangunan sipil, seperti dalam stabilisasi tanah [8], [9], [11], [12]. Stabilisasi tanah dengan fly ash telah diterapkan sebagai alternatif yang efektif untuk peningkatan kekuatan dan kekakuan tanah melalui reaksi kimia [13], [14]. Peningkatan ini terjadi karena beberapa jenis fly ash mengandung kapur $(\mathrm{CaO})$ dan pozolan yang terdiri dari senyawa silika $\left(\mathrm{SiO}_{2}\right)$ dan alumina $\left(\mathrm{Al}_{2} \mathrm{O}_{3}\right)$. Ketika fly ash dicampur dengan tanah serta air, terjadi reaksi kimia [15]. Reaksi kimia ini memisahkan kapur $(\mathrm{CaO})$ dalam fly ash dan melakukan proses sementasi dan senyawa pozzolan yang terdiri dari senyawa kalsium silikat hidrat (CSH) dan senyawa kalsium aluminate hidrat (CAH). Akibatnya, fly ash akan mengikat partikel tanah dan meningkatkan kekuatan dan kekakuan tanah tersebut [16]-[18].

Penyelidikan laboratorium pada sifat mekanik tanah yang distabilisasi dengan fly ash, seperti tes pada kuat tekan bebas, kuat geser, california bearing ratio (CBR), modulus resilien, dan lain-lain telah sering dilakukan [12]-[14], [19], [20]. Penelitian mengenai stabilisasi tanah kohesif menggunakan material fly ash telah banyak dilakukan. Tetapi penelitian mengenai stabilisasi atau perbaikan sifat - sifat mekanik tanah non kohesif dengan fly ash masih sangat terbatas informasinya.

Berdasarkan paparan yang telah diuraikan di atas, maka penelitian ini memanfaatkan limbah abu batu bara (fly ash) sebagai material pengikat pasir berbutir halus dalam kondisi jenuh air $\left(\mathrm{S}_{\mathrm{r}}=100 \%\right)$. Tingkat kepadatan contoh material adalah medium (serupa kondisi yang berpotensi likuifaksi). Tujuan utama penelitian ini adalah untuk mengetahui perubahan kharakteristik atau sifat - sifat mekanik dari material komposit akibat penambahan fly ash dan waktu kuring.

Dalam penelitian ini, hubungan tegangan-regangan yang menggambarkan perubahan perilaku material komposit akibat beban kerja, baik beban vertikal maupun beban geser telah dibuat. Termasuk di dalamnya regangan maksimum yang bisa dipikul material komposit sebelum mengalami kegagalan (failure). Untuk mengetahui pengaruh fly ash terhadap nilai kuat tekan bebas dan kuat geser pasir halus, uji tekan bebas dan geser langsung telah dilakukan dalam berbagai variasi fly ash dan waktu kuring. Dalam variasi tersebut, perubahan dalam parameter kuat geser berupa kohesi "c" dan sudut geser " $\theta$ " juga telah dilakukan. Dalam hubungan dengan sudut geser material komposit, perubahan angularitas relatif akibat penambahan fly ash dan masa kuring telah diteliti.

\section{METODE}

Penelitian ini adalah penelitian eksperimental yang dilaksanakan di Laboratorium Mekanika Tanah, Fakultas Teknik, Universitas Halu Oleo Kendari sejak bulan April 2019 sampai dengan Juli 2020. Bahan-bahan yang digunakan berupa agregat halus, fly ash, dan air, sebagaimana diuraikan berikut ini.

\section{Agregat Halus}

Agregat halus yang digunakan dalam penelitian ini adalah pasir dari Sungai Pohara/Konawe'eha Provinsi Sulawesi Tenggara dengan gradasi butiran pasir 0,3 - 0,075 $\mathrm{mm}$ atau butiran yang lolos saringan no.40 dan tertahan pada saringan no.200. Pasir halus yang digunakan dalam keadaan kering oven.

\section{Fly Ash}

Fly ash yang digunakan berasal dari PLTU Nii Tanasa, desa Nii Tanasa, Kec. Lalonggasumeeto, Kabupaten Konawe, Provinsi Sulawesi Tenggara. 
Fly ash ini diklasifikasikan sebagai fly ash tipe C [21], yang memiliki kandungan $\mathrm{CaO}$ lebih dari $20 \%$. Rasio $\mathrm{CaO} / \mathrm{SiO}_{2}$ dari abu terbang ini lebih dari 1 [9], menunjukkan bahwa fly ash ini adalah bahan stabilizer yang baik dan efektif sebagai bahan sementasi. Dalam penelitian ini variasi kadar fly ash yang digunakan yaitu 5\%, 10\%, 15\%, 20\%, 25\% dan $30 \%$.

Air

Air yang digunakan adalah air yang memenuhi persyaratan, yaitu air bersih dan jernih, tidak mengandung lumpur, minyak dan benda yang melayang lainnya lebih dari 2 gram/liter.

Nilai kepadatan relatif $\left(D_{r}\right)$ seluruh sampel dalam penelitian ini ditetapkan sebesar 50\% serta nilai derajat kejenuhan $\left(S_{r}\right)$ sebesar $100 \%$ (jenuh sempurna). Variabel penelitian berupa variasi kadar fly ash dan waktu perawatan. Kadar fly ash terdiri dari 5\%, 10\%, 15\%, 20\%, 25\%, dan 30\% serta perlakuan variasi waktu perawatan (curing) yaitu 7 hari, 14 hari, 28 hari dan 56 hari. Jumlah sampel untuk setiap komposisi campuran berjumlah tiga buah, baik untuk uji tekan bebas maupun geser langsung. Sebelum memasuki tahap mix design, terlebih dahulu dilakukan pengujian terhadap kharakteristik material yang akan digunakan terdiri atas:

1) Pemeriksaan gradasi pasir dan fly ash [22]

2) Pemeriksaan berat jenis pasir [23]

3) Pemeriksaan berat isi pasir halus [24]

Setelah data kharakteristik bahan sudah didapatkan melalui berbagai jenis pengujian, selanjutnya dilakukan formulasi untuk mendapatkan komposisi setiap material atau bahannya (mix design) dengan menggunakan persamaan - persamaan dasar dalam ilmu mekanika tanah dan teknologi bahan konstruksi. Pasir, fly ash, dan air dicampur sesuai dengan komposisi mix design, seperti ditunjukkan pada Gambar 1(a) dan (b). Proses pembuatan campuran dilakukan secara manual menggunakan wadah nampan stainless dengan alat pencampur berupa sendok semen/makan (Gambar 1(c)) serta dapat menggunakan wadah berupa plastik klip tanpa alat pencampur dengan cara kerja memasukan semua bahan ke dalam plastik klip kemudian campur secara merata dengan pijatan tangan dan diguncangguncang. Proses pencampuran dilakukan secepat mungkin untuk meminimalisir penguapan air campuran ke udara (Gambar 1(d)). Setelah campurannya homogen yang ditandai dengan warna campurannya merata, selanjutnya dilakukan proses pencetakan dengan menggunakan wadah cetakan yang telah disiapkan.

Cetakan terbuat dari pipa PVC ukuran 2" - 2,5". Dimensi cetakan sampel kuat tekan bebas berdiameter $5,5 \mathrm{~cm}$ dengan tinggi $11 \mathrm{~cm}$, sedangkan untuk dimensi sampel kuat geser berdiameter $6,5 \mathrm{~cm}$ dan tinggi $2,2 \mathrm{~cm}$. Timbang cetakan yang akan digunakan dan catat massanya serta berikan label yang jelas. kemudian campuran dimasukkan ke dalam cetakan secara bertahap atau per lapisan/layer hingga cetakan penuh. Disetiap layer dilakukan pemadatan dengan penumbukan lalu diberi pola berjaring agar layer berikutnya dapat melekat dengan baik. Setelah cetakan penuh, dilakukan penimbangan massa sampel + cetakan (Gambar $1(\mathrm{e})$ ).

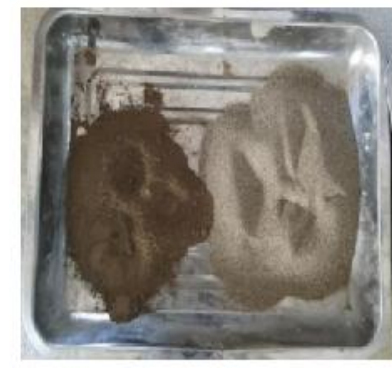

(a)

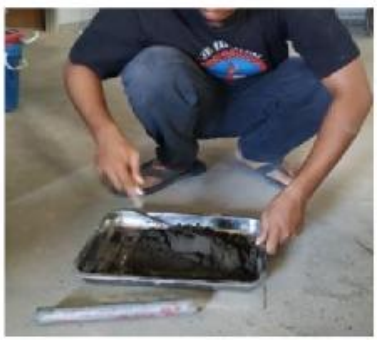

(c)

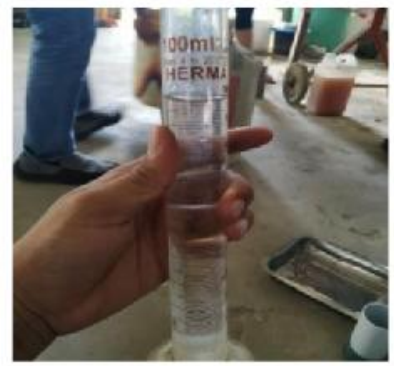

(b)

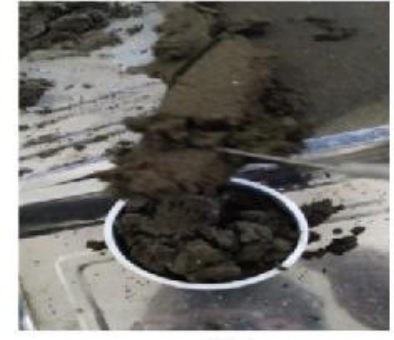

(d)

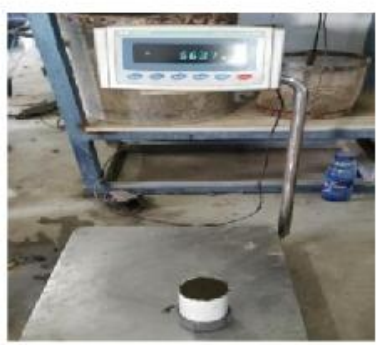

(e)

Gambar 1. Proses pembuatan material komposit (a) pasir halus dan fly ash sesuai komposisi mix design; (b) massa air sesuai komposisi mix design; (c) proses pencampuran; (d) proses pencetakan; (e) menimbang massa sampel + cetakan. 


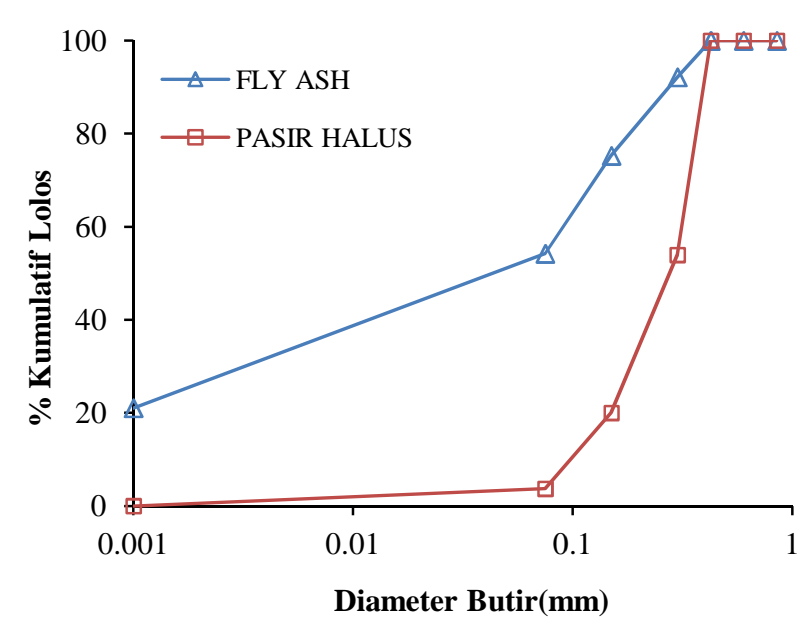

Gambar 4. Analisa saringan pasir dan fly ash Selanjutnya dilakukan pengecekan terhadap gradasi pasirnya apakah telah memenuhi syarat sebagai pasir halus berdasarkan batas - batas gradasi agregat halus yang terbagi dalam 4 zona dimana pasir halus berada dalam zona IV yang dijabarkan dalam SNI 03-28341992. Gambar 5 menunjukkan batas gradasi zona IV agregat halus.

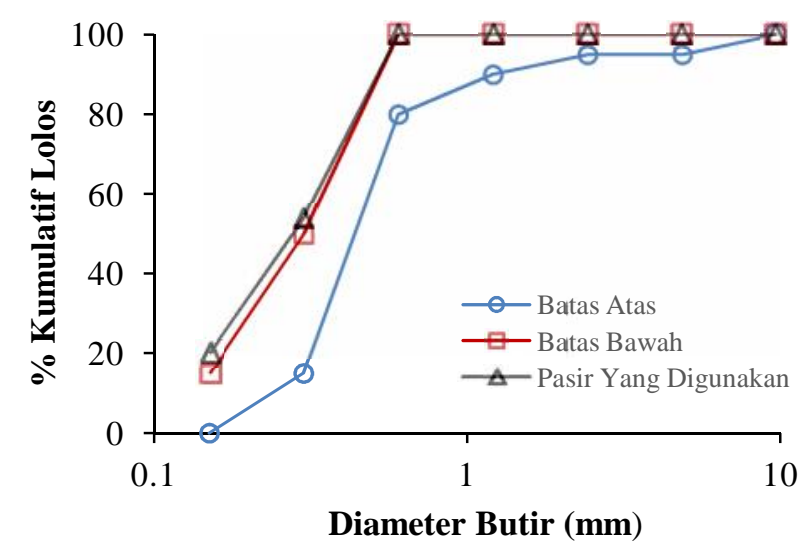

Gambar 5. Batas gradasi zona IV agregat halus berdasarkan SNI 03-2834-1992

Berdasarkan pengamatan dari Gambar 5, didapatkan hasil bahwa pasir yang digunakan dikategorikan sebagai pasir halus atau masuk dalam range kurva batas atas dan tepat pada garis kurva batas bawah zona IV agregat halus.

\section{Berat Jenis dan Berat Isi Pasir Halus}

Berat jenis, berat isi pasir halus baik lepas maupun padat, dan angka pori dalam kondisi maksimum dan minimum yang didapatkan dari hasil pengujian ditunjukkan pada Tabel 1.

Tabel 1. Sifat fisik dan distribusi ukuran butir

\begin{tabular}{cccc}
\hline Properti & Simbol & Nilai & Satuan \\
\hline Berat Jenis & Gs & 2,67 & - \\
Berat isi pasir lepas & $\rho_{\text {min }}$ & 1,20 & $\mathrm{gr} / \mathrm{cm}^{3}$ \\
Berat isi pasir padat & $\rho_{\text {maks }}$ & 1,42 & $\mathrm{gr} / \mathrm{cm}^{3}$ \\
Angka pori maksimum & $\mathrm{e}_{\text {maks }}$ & 1,23 & - \\
Angka pori minimum & $\mathrm{e}_{\min }$ & 0,88 & - \\
\hline
\end{tabular}

\section{Mix Design Material Komposit}

Hasil mix design material komposit yang dibedakan berdasarkan jenis pengujian sifat mekaniknya, yaitu uji kuat tekan bebas (UCS) dan uji kuat geser langsung (DS), diperoleh data sebagaimana pada Tabel 2.

Tabel 2. Mix design material komposit $\left(\mathrm{D}_{\mathrm{r}}=50 \%\right.$ dan $\mathrm{S}_{\mathrm{r}}=100 \%$ )

\begin{tabular}{cccc}
\hline \multicolumn{2}{c}{ Massa Pasir+Fly Ash (gr) } & \multicolumn{2}{c}{ Volume Air (ml) } \\
UCT & DS & UCT & DS \\
\hline 340 & 95 & 134 & 37.5 \\
\hline
\end{tabular}

Untuk mengetahui apakah sampelnya telah berada pada kondisi kepadatan relatif $50 \%$ atau derajat kejenuhan $100 \%$, maka berat/volume total sampel material komposit harus berada pada kisaran seperti pada Tabel 4, dengan catatan dimensi sampel tidak berubah atau rusak sesuai yang direncanakan.

\section{Kuat Tekan Bebas}

Uji kuat tekan bebas dilakukan dengan kondisi sudut geser dalam $(\varnothing=0)$ dan tahanan samping $\left(\sigma_{3}=0\right)$, jadi hanya ada beban vertikal $\left(\sigma_{1}=0\right)$ dengan memberikan deformasi [28]. Hubungan tegangan dan regangan dalam berbagai variasi kadar fly ash serta waktu kuring hasil uji ini disajikan pada Gambar 6. 


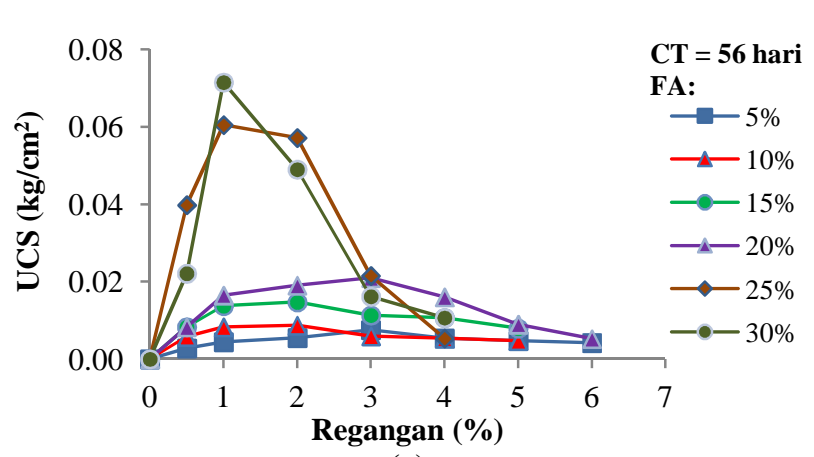

(a)

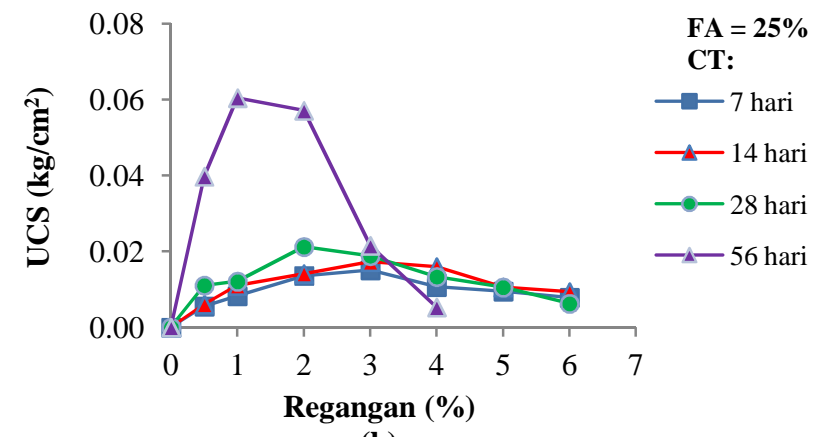

(b)

Gambar 6. Hubungan tegangan dan regangan (a) variasi fly ash (FA), (b) variasi waktu kuring (CT)

Gambar 6 menunjukkan bahwa sampel dengan persen fly ash 5\% memiliki tegangan aksial terkecil. Pada sampel dengan kadar fly ash $30 \%$ nilai tegangan meningkat lebih tinggi atau memiliki tegangan aksial terbesar dari variasi lain. Berdasarkan perbandingan data - data di atas, diketahui bahwa nilai kuat tekan cenderung mengalami peningkatan atau berbanding lurus terhadap bertambahnya kadar fly ash dalam campuran material komposit, dengan waktu kuring yang sama. Kenaikan nilai kuat tekan ini disebabkan oleh adanya proses sementasi dan self-hardening hasil dari reaksi kimia fly ash dengan air terhadap pasir halus selama masa curing yang awalnya berupa butiran lepas menjadi partikel padat yang lebih besar.

Jumlah atau komposisi senyawa kimia yang menyebabkan proses sementasi dari fly ash bertambah seiring dengan bertambahnya \% fly ash, sehingga ikatan antar partikel atau butiran dalam material komposit bertambah kuat atau makin solid. Analogi bertambahnya nilai tegangan aksial meningkat seiring dengan bertambahnya kadar fly ash juga dapat ditinjau dari hasil analisa saringan pada pembahasan sebelumnya. Partikel fly ash memiliki ukuran butiran lebih kecil dibanding ukuran butiran pasir halus sehingga fly ash menjadi filler atau pengisi pori-pori dari pasir halus.

Disisi lain, bertambahnya kadar fly ash mempengaruhi posisi koordinat titik puncak hubungan tegangan-regangan. Posisi puncak cenderung bergeser ke arah kiri dari sumbu $\mathrm{x}$ atau sumbu regangan (makin memendek). Hal ini pun berbanding lurus terhadap nilai kuat tekan bebas material komposit yang mengalami peningkatan.

Kecenderungan yang sama juga diperoleh pada variasi waktu kuring, seperti ditunjukkan pada Gambar 6(b). Berdasarkan grafik - grafik tersebut dapat dilihat bahwa nilai kuat tekan bebas cenderung mengalami peningkatan atau berbanding lurus terhadap bertambahnya waktu kuring. Meningkatnya nilai kuat tekan disebabkan karena proses hidrasi dari air terhadap fly ash (bagian dari proses sementasi) yang belum sepenuhnya sempurna. Proses hidrasi fly ash ini terus terjadi atau berlangsung seiring dengan bertambahnya masa kuring hingga prosesnya menjadi jenuh atau sempurna. Dalam kasus penelitian ini belum ditemukan batas waktu saat sempurnanya proses hidrasi tersebut namun terus berlangsung hingga umur sampel mencapai 56 hari yang ditandai dengan terus meningkatnya nilai kuat tekan sampel. Kecenderungan sebagaimana disebutkan di atas sejalan dengan hasil penelitian yang dilakukan oleh para peneliti sebelumnya [10], [29]-[32].

\section{Pengaruh Kadar Fly Ash dan Waktu Kuring Terhadap Nilai Kuat Tekan Bebas Material Komposit.}

Perubahan nilai kuat tekan maksimum pada sampel - sampel material komposit yang tinjau berdasarkan parameter variasi kadar fly ash dan waktu kuring dapat dilihat pada Gambar 7 berikut ini. 


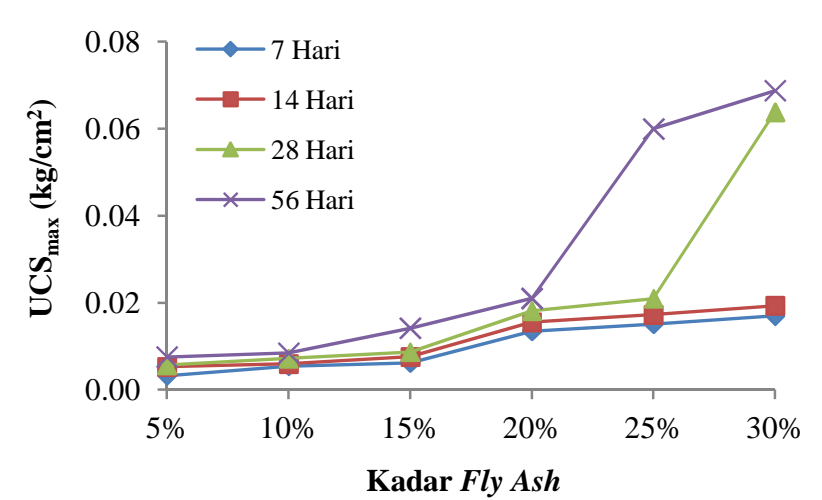

Gambar 7. Kuat tekan bebas maksimum material komposit dalam berbagai variasi kadar fly ash dan waktu kuring

Grafik- grafik pada gambar tersebut menunjukkan bahwa nilai kuat tekan mengalami peningkatan seiring dengan penambahan fly ash dan waktu kuring. Berdasarkan dari segi persentase, peningkatan, kuat tekan terbesar terjadi pada sampel yang di kuring selama 28 hari. Peningkatan yang terjadi mencapai 204,5\%. Dari segi nilai kuat tekan, sampel - sampel dengan kandungan fly ash dan waktu kuring terbesar menghasilkan nilai kuat tekan terbesar pula. Proses sementasi dan self-hardening hasil dari reaksi kimia fly ash dengan air terhadap pasir halus selama masa kuring mampu menciptakan ikatan antar butiran pasir. Ikatan ini secara langsung meningkatkan kekuatan dan tahanan terhadap tekan dari material komposit. Peningkatan sifat-sifat mekanis material komposit fly ash dan pasir selama masa kuring menunjukkan kecenderungan yang sama dengan hasil penelitian sebelumnya [11], [30], [33].

\section{Kuat Geser Langsung}

Kuat geser tanah merupakan perlawanan internal tanah per satuan luas terhadap keruntuhan atau pergerakan sepanjang bidang geser dalam tanah [34]. Kekuatan geser tanah (soil shear strength) dapat didefinisikan sebagai kemampuan maksimum tanah untuk bertahan terhadap usaha perubahan bentuk pada kondisi tekanan (pressure) dan kelembapan tertentu [28]. Uji kuat geser langsung pada penelitian ini menggunakan 3 macam beban aksial, yaitu $4 \mathrm{~kg}, 8 \mathrm{~kg}$, dan $12 \mathrm{~kg}$. Perwakilan hubungan tegangan - regangan terhadap variasi kadar fly ash serta variasi waktu kuring ditunjukkan pada Gambar 8.

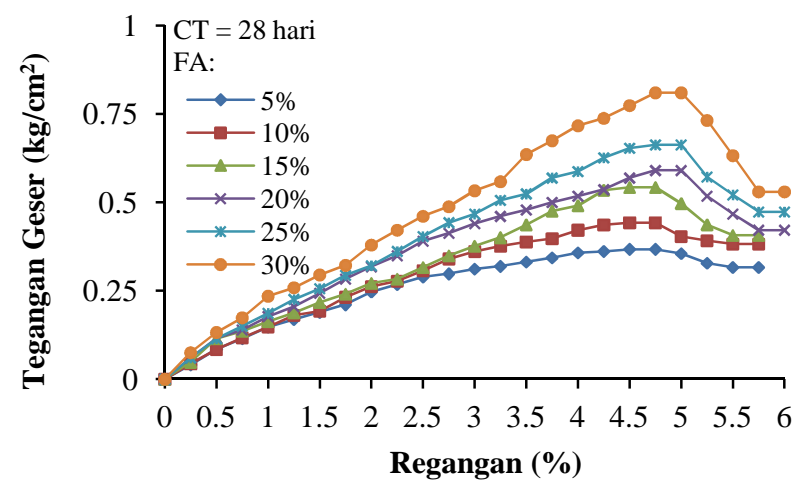

(a)

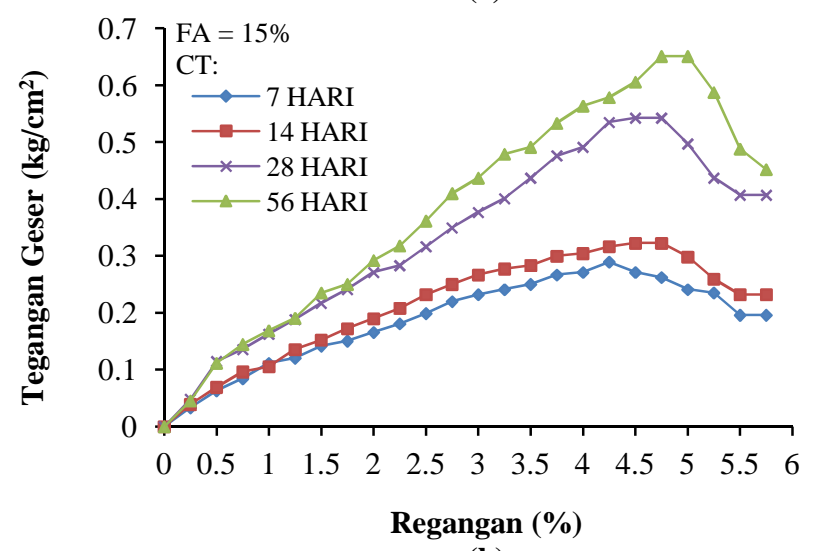

(b)

Gambar 8. Hubungan tegangan - regangan pada pengujian kuat geser langsung dengan menggunakan beban normal $12 \mathrm{~kg}$ pada variasi (a) fly ash, (b) waktu kuring

Sebagaimana pada uji tekan bebas, dari Gambar 8 diketahui bahwa nilai kuat geser puncak cenderung mengalami peningkatan atau berbanding lurus terhadap bertambahnya kadar fly ash dalam campuran material komposit dan bertambahnya waktu kuring. Catatan-catatan dalam penelitian terdahulu menunjukkan kecenderungan yang sama dengan hasil penelitian ini. Reaksi pozzolan dan proses sementasi fly ash menjadi faktor penentu dalam kasus ini, seperti juga dijelaskan dalam penelitian terdahulu [10], [29]-[32].

\section{Pengaruh Kadar Fly Ash Terhadap Nilai Kohesi dan Sudut Geser Material Komposit.}

Parameter kuat geser material komposit, berupa nilai kohesi dan sudut geser, dihitung menggunakan teori keruntuhan dari Mohr-Coulomb, seperti ditunjukkan pada Gambar 9. Dasarnya adalah grafik hubungan tegangan geser dan tegangan normal. Salah satu contoh dalam penelitian ini ditunjukkan pada 
Gambar 9. Sampel material komposit yang dikuring selama 7 hari pada kandungan kadar fly ash yang berbeda atau bervariasi dibebani dengan beban normal sebesar $0.12,0.24$, dan $0.36 \mathrm{~kg} / \mathrm{cm}^{2}$.

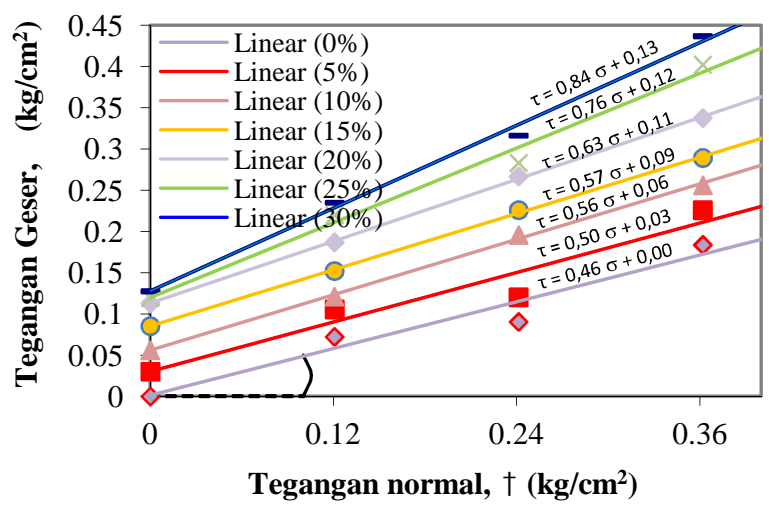

Gambar 9. Hubungan tegangan geser dan tegangan normal pada material komposit yang di kuring selama 7 hari

Dari Gambar 9 terlihat bahwa nilai kohesi maupun sudut geser meningkat seiring bertambahnya kadar fly ash di dalam material komposit. Pada berbagai variasi waktu kuring disisi lain, perubahan nilai kohesi dan sudut geser material komposit untuk variasi kadar fly ash seperti pada Gambar 9 dapat dilihat pada Gambar 10.

Berdasarkan Gambar 10, nilai kohesi dan sudut geser material komposit yang dikelompokkan berdasarkan masa kuring 7, 14, 28, dan 56 hari serta variasi campuran kadar fly ash 5\%, 10\%, 15\%, 20\%, $25 \%$, dan $30 \%$ mengalami peningkatan seiring dengan masa kuring dan kadar FA. Sebagaimana kuat tekan dan kuat geser, nilai kohesi dan sudut geser terbesar juga terjadi pada kandungan FA dan masa kuring terbesar.

Peningkatan sudut geser akibat penambahan fly ash disebabkan oleh bertambah besarnya butiran pasir akibat ikatan fly ash di permukaannya. Perbandingan ukuran kristal fly ash yang menempel di permukaan pasir dengan ukuran butiran pasir itu sendiri diistilahkan dengan angularitas relatif [8], [9]. Semakin besar persentase fly ash yang dicampur ke material pasir, maka angularitas relatif pasir yang mungkin terjadi juga akan semakin besar.

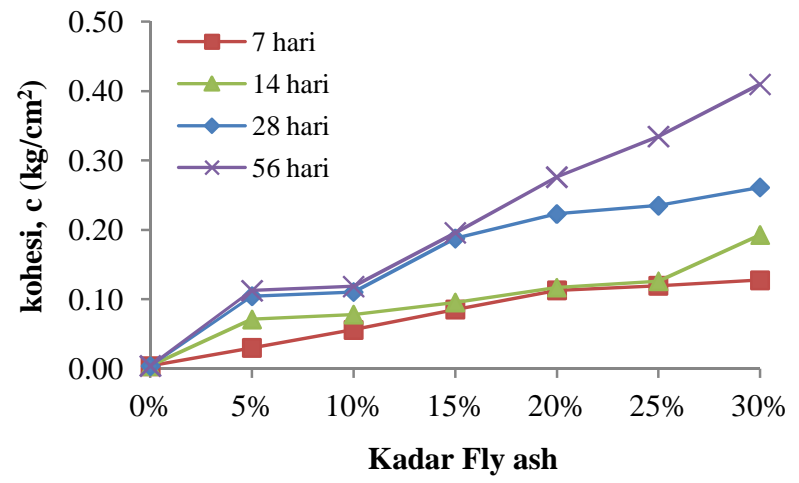

(a)

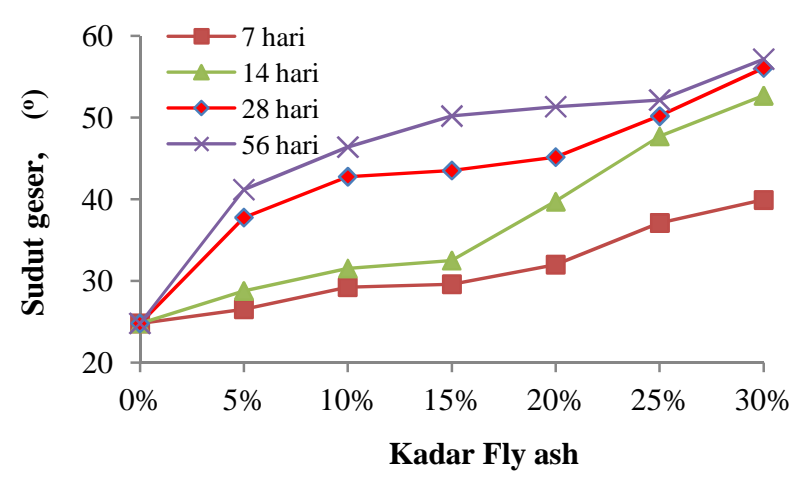

(b)

Gambar 10. Kohesi dan sudut geser material komposit pada berbagai variasi kadar fly ash dan waktu kuring

Mekanismenya bisa dijelaskan sebagai berikut. Seiring dengan masa kuring dan sifat dasar fly ash bila dicampur dengan air, proses sementasi dan reaksi pozzolan terjadi terus menerus. Proses ini terjadi selama air yang terkandung dalam material komposit masih cukup untuk mengurai kapur yang terkandung di dalam fly ash. Akibatnya angularitas relatif akan terus meningkat, sekaligus menaikkan nilai kohesi dan sudut geser. Penelitian-penelitian sebelumnya pada tanah yang distabilisasi dengan fly ash juga menunjukkan hal yang sama [8]-[10], [13], [30], [32], [35].

\section{KESIMPULAN}

Dalam penelitian ini, kuat tekan bebas dan kuat geser material komposit berbahan dasar fly ash dan pasir halus telah diobservasi. Tujuannya adalah untuk mengetahui pengaruh penambahan fly ash dan 
waktu kuring terhadap perubahan sifat-sifat mekanis tanah berbutir lepas. Sampel material komposit dibentuk pada derajat kejenuhan sempurna dan dites menggunakan alat uji tekan bebas dan uji geser langsung. Kandungan fly ash 5-30\% dengan kenaikan 5\% dan waktu kuring 7, 14, 28, dan 56 hari. Kesimpulan utama yang diperoleh disusun sebagai berikut.

Kadar fly ash dan waktu kuring memberikan pengaruh nyata terhadap hubungan teganganregangan pada uji kuat tekan dan kuat geser dari material komposit (campuran pasir halus, fly ash dan air). Posisi atau koordinat titik puncak kurva tegangan-regangan akibat tekan cenderung bergeser ke arah kiri dari sumbu $\mathrm{x}$. Sumbu regangan makin memendek jika kadar fly ash dan waktu kuring material komposit bertambah atau meningkat. Ikatan fly ash cenderung menunjukkan sifat getas seiring dengan penambahan fly ash dan waktu kuring.

Hubungan tegangan dan regangan hasil uji kuat geser langsung berbanding terbalik dengan hasil uji kuat tekan bebas. Posisi atau koordinat titik puncak kurva tegangan geser cenderung makin memanjang atau bergeser ke arah kanan dari sumbu regangan. Angularitas relatif semakin besar jika kadar fly ash dan waktu pemeraman material komposit bertambah atau meningkat.

Kuat tekan dan kuat geser cenderung mengalami peningkatan seiring dengan bertambahnya kadar fly ash dalam campuran material komposit dan bertambahnya waktu kuring. Reaksi pozzolan dan proses sementasi menjadikan material komposit semakin kompak dan semakin kuat. Hidrasi semen menjadikan ikatan antar butiran semakin kuat.

Nilai kohesi dan sudut geser cenderung mengalami peningkatan terhadap bertambahnya masa kuring dan bertambahnya kadar fly ash dalam campuran material komposit. Peningkatan ini bergerak terus menerus selama masa kuring, hingga proses sementasi dan reaksi pozzolan berhenti. Waktu yang dibutuhkan oleh material komposit yang berbahan dasar fly ash sebagai bahan pengikat melebihi waktu yang dibutuhkan oleh semen untuk mencapai kekutan maksimumnya, yaitu lebih dari 28 hari. Penelitian lanjutan untuk kasus ini masih sangat dibutuhkan.

\section{DAFTAR PUSTAKA}

[1] M. Simatupang, M. Okamura, K. Hayashi, and H. Yasuhara, "Small-strain Shear Modulus and Liquefaction Resistance of Sand with Carbonate Precipitation," Soil Dyn. Earthq. Eng., vol. 115, no. 2018, pp. 710-718, 2018.

[2] M. Simatupang and M. Okamura, "Liquefaction Resistance of Sand Remediated with Carbonate Precipitation at Different Degrees of Saturation during Curing," Soils Found. Japanese Geotech. Soc., vol. 57, no. 4, pp. 619-631, 2017.

[3] M. Simatupang, A. S. Sukri, Nasrul, Sulha, and T. S. Putri, "Effect of Confining Pressures on the Shear Modulus of Sand Treated with Enzymatically Induced Calcite Precipitation," IOP Conf. Ser. Mater. Sci. Eng., vol. 615, no. 1, pp. 1-9, 2019.

[4] Y. Xiao, X. He, T. M. Evans, A. W. Stuedlein, and H. Liu, "Unconfined Compressive and Splitting Tensile Strength of Basalt Fiber-Reinforced Biocemented Sand," J. Geotech. Geoenvironmental Eng., vol. 145, no. 9, 2019.

[5] R. L. Parsons and E. Kneebone, "Field Performance of Fly Ash Stabilised Subgrades," Gr. Improv., vol. 9, no. 1, pp. 33-38, 2005.

[6] S. Lirer, B. Liguori, I. Capasso, A. Flora, and D. Caputo, "Mechanical and Chemical Properties of Composite Materials Made of Dredged Sediments in a Fly-ash based Geopolymer," J. Environ. Manage., vol. 191, pp. 1-7, 2017.

[7] I. Capasso et al., "Reuse of Mining Waste as Aggregates in Fly ash-based Geopolymers," J. Clean. Prod., vol. 220, 2019.

[8] M. Simatupang, "Effectiveness of Lowering Saturation on Residual Shear Strength of Sand Stabilized with Fly-Ash," IOP Conf. Ser. Earth Environ. Sci., vol. (In Press), 2020.

[9] M. Simatupang et al., "The Mechanical Properties of Fly-Ash-Stabilized Sands," Geosciences, vol. 10, no. 4, pp. 1-19, 2020.

[10] K. Harichane, M. Ghrici, and S. Kenai, "Effect of Curing Time on Shear Strength of Cohesive Soils Stabilized with Combination of Lime and Natural Pozzolana," Int. J. Civ. 
Eng., vol. 9, no. 2, pp. 90-96, 2011.

[11] J. N. Jha, K. S. Gill, and A. K. Choudhary, "Effect of High Fraction Class F Flyash on Lime Stabilization of Soil," Int. J. Geotech. Environ., vol. 1, no. 2, pp. 105-128, 2009.

[12] E. O. Tastan, T. B. Edil, C. H. Benson, and A. H. Aydilek, "Stabilization of Organic Soils with Fly Ash," J. Geotech. Geoenvironmental Eng. ASCE, vol. 137, no. September, pp. 819-833, 2011.

[13] J. Prabakar, N. Dendorkar, and R. K. Morchhale, "Influence of Fly Ash on Strength Behavior of Typical Soils," Constr. Build. Mater., vol. 18, no. 2004, pp. 263267, 2004.

[14] B. B. D. Trzebiatowski, T. B. Edil, and C. H. Benson, "Case Study of Subgrade Stabilization using Fly Ash: State Highway 32, Port Washington, Wisconsin," Recycl. Mater. Geotech., pp. 123-136, 2004.

[15] N. Cesar, H. Batista, S. Carretta, L. Daronco, and D. E. Lourenc, "The Effects of Curing Time and Temperature on Stiffness, Strength and Durability of Sand-Environment Friendly Binder Blends," no. xxxx, 2019.

[16] A. A. Amadi and A. S. Osu, "Effect of Curing Time on Strength Development in Black Cotton Soil - Quarry Fines Composite Stabilized with Cement Kiln Dust ( CKD )," J. King Saud Univ. - Eng. Sci., vol. 30, no. 4, pp. 305-312, 2018.

[17] F. O. P. Oriola and G. Moses, "Compacted Black Cotton Soil Treated with Cement Kiln Dust as Hydraulic Barrier Material," Am. J. Sci. Ind. Res., vol. 2, no. 4, pp. 521-530, 2011.

[18] A. B. Salahudeen, A. . Eberemu, and K. J. Osinubi, "Assessment of Cement Kiln DustTreated Expansive Soil for the Construction of Flexible Pavements," Geotech. Geol. Eng., 2014.

[19] R. M. Brooks, "Soil Stabilization With Flyash and Rice Husk Ash," Int. J. Res. Rev. Appl. Sci., vol. 1, no. 3, pp. 2076-7366, 2009.

[20] T. B. Edil, H. A. Acosta, and C. H. Benson, "Stabilizing Soft Fine-Grained Soils with Fly Ash," J. Mater. Civ. Eng., vol. 18, no. 2, pp. 283-294, 2006.

[21] Badan Standardisasi Nasional, "SNI 2460:2014 Spesifikasi Abu Terbang Batubara dan Pozolan Alam Mentah atau yang telah Dikalsinasi untuk Digunakan dalam Beton," p. 16, 2014.

[22] SNI 03-1968, "Metode Pengujian Tentang Analisi Saringan Agregat Halus dan Kasar," Badan Standar Nas. Indones., pp. 1-5, 1990.

[23] Badan Standardisasi Nasional, "SNI 1964:2008 Cara Uji Berat Jenis Tanah,” p. 14, 2008.

[24] SNI 03-4804, "Metode Pengujian Bobot Isi dan Rongga Udara dalam Agregat," Balitbang PU, pp. 1-6, 1998.

[25] Badan Standardisasi Nasional, "SNI 3638: Metode Uji Kuat Tekan-Bebas Tanah Kohesif," 2012.

[26] Badan Standardisasi Nasional, "SNI 3420:2016 Metode Uji Kuat Geser Langsung Tanah Tidak Terkonsolidasi dan Tidak Terdrainase," 2016.

[27] B. M. Das, Principles of Geotechnical Engineering, Seventh. Stamford, USA: Cengange Learning, 2010.

[28] H. C. Hardiyatmo, "Mekanika Tanah I Jilid III," p. 1, 2002.

[29] G. Gay and H. Schad, "Influence of Cement and Lime Additives on the Compaction Properties and Shear Parameters of Fine Grained Soils," Otto Graf J., vol. 11, pp. 1932, 2000.

[30] A. Sezer, G. Inan, H. R. Yilmaz, and K. Ramyar, "Utilization of a Very High Lime Fly Ash for Improvement of Izmir Clay," Build. Environ., vol. 41, pp. 150-155, 2006.

[31] F. G. Bell, "Lime Stabilization of Clay Soils," Bull. Int. Assoc. Eng. Geol., vol. 39, pp. 67-74, 1989.

[32] S. A. Ola, "Geotechnical Properties and Behaviour of Some Stabilized Nigerian Lateritic Soils Geotechnical Properties and Behaviour of Some Stabilized Nigerian Lateritic Soils," Q. J. Eng. Geol. Hydrogeol. Geotech., vol. 11, pp. 145-160, 1978.

[33] S. Jalali, M. Y. Abyaneh, and M. J. Keedwell, "Differential Scanning Calorimetry Tests Applied to Lime - Fly Ash Soil Stabilization," Test. Soil Mix. with Waste or Recycl. Mater. STP 1275. ASTM, West Conshohocken, pp. 181-191, 1997.

[34] B. M. Das, N. Endah, and I. B. Mochtar, "Mekanika Tanah Jilid 1 (Prinsip-prinsip Rekayasa Geoteknis)," Erlangga, pp. 1-291, 
1995.

[35] A. Sridharan, J. P. Prashanth, and P. V Sivapullaiah, "Effect of Fly Ash on the Unconfined Compressive Strength of Black Cotton Soil," Gr. Improv., vol. 1, pp. 169175, 1997. 